\title{
DEVELOPMENT OF THE COEFFICIENT OF INBREEDING AND RELATIONSHIP IN THE FINNISH AYRSHIRE BREED.
}

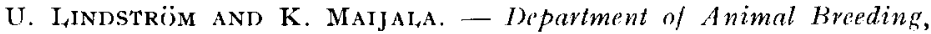 \\ Agricultural Reseavch Centre, Tikkurila, Finland.
}

On the basis of samples of cows taken from the herd hook (4-lines pedigrees carried back to 1894-97) and on pedigree information (7 generations) for AI bulls the level of inbreeding and relationship in the Finnish Ayrshire breed was studied. By year of birth, samples of 50 cows were taken for each of the years $1915,-25,-35,-45,-55$ and -60 as well as a sample of 100 cows for the year 1965 . The 783 AI bulls analysed were born between 1939 and 1962 .

The coefficient of relationship rose from $2.0 \pm 0.5$ per cent in 1915 to $7.3 \pm 0.6$ per cent in 1965 and has, in the period 1945-65, remained at the same level. Over the whole period studied the coefficient rose, on an average, 0.77 per cent/generation, i. e. 0.1 à 1 per cent/year.

The coefficient of inbreeding $\left(\mathrm{F}_{x}\right)$ rose from $1.2 \neq 0.4$ per cent in 1915 to $3.2 \pm 0.4$ per cent in 1965. Up to 1935 the observed coefficients were in agreement with those expected on the basis of the degree of relationship. In the following 20 years period the observed $F_{x}$ values were some 2 per cent units lower than the expected ones. Over the whole period studied the coefficient rose, on an average, $0.34 \mathrm{per}$ cent/generation, i. e. $0.05 \mathrm{per}$ cent/year.

The Scottish ancestors' proportion of the genes increased from 65 per cent in 1915 to 92 per cent in 1965. On an average the earlier importations accounted for 59-72 per cent of the genes. Those imported in 1923 have since 1935 accounted for at least $1 / 5$ of the genes. The Ayrshire animals imported from Sweden accounted for 14-17 per cent of the genes in 1915-35, but only for 4,5-5,0 per cent in 1955-65. Ancestors of native or unknown origin accounted for over 21 per cent of the genes in 1915, but only for 3-8 per cent in 1945-65.

The relationship of the AI bulls to 7 prominent ancestors varied, on an average, between 2.4 and 12.6 per cent. There was a slight tendency for the degree of relationship to decrease with decreasing age of the bull categories.

The mean $F_{x}$ for $A I$ bulls born in 1939-44, 1945-49, 1950-54, 1955-59 and 1960-62 were $2.1,4.1,3.3,2.4$ and 2.3 per cent, respectively. Thus there was no significant trend in the development. Only 28 bulls $\left(3.6 \%\right.$ ) had an $\mathrm{F}_{x}$ of 9 per cent or more, over 90 per cent hăd less than 6 per cent.

The bull South Craib Snowball A 3399 (imported in 1923 from Scotland) was the individual influencing the breed mostly. His direct relationship to the cows increased from 1 per cent in 1925 to 14.8 per cent in 1965 . His relationship to the AI bulls in use in 1955 was 16.4 per cent and to those in use in 196012.4 per cent.

\section{Gewinnfunktionen - ein Hilffsmittel für die Planung von GEBRAUCHSKREUZUNGEN BEIM SCHWEIN}

\author{
F. FEwsoN. - Institut für Tierzüchtung und Tierhaltung der Universitä \\ Hohenheim - BRD.
}

V. JakUBFC. - Forschungsinstitut für Tierzucht in Uhrineves bei Prag - CSSR

Aufbauend auf den Arbeiten von Suтt (1964), Moav und Moav (1966, Breed. Poult. Sci., 7, 5) sowie MoAv (1966, Anim. Prod., 8, 193, 203, 365) wurden Gewinnfunktionen für die Reinzucht und Gebrauchskreuzung beim Schwein entwickelt. In der allgemeinen Gewinnfunktion für die Schweineproduktion wird mit einer variablen Erlöskomponente/Qualitäts-bzw.-abschläge/gerechnet, in die verschiedene Merkmale der Schlachtkörperqualität eingehen können. 